\title{
Lament i konsolacja. O dwóch obrazach Boga w tekstach z getta warszawskiego ${ }^{1}$
}

\section{Lament and Consolation: On Two Images of God in the Texts from the Warsaw Ghetto}

Abstract: The author compares the descriptions of the two opposite religious experiences engendered in the period of destruction of the Warsaw ghetto, and the two images of God connected to it. One experience emerges from the consolation sermons of rabbi Kelman Szapira from Piaseczno, in which the immense suffering of the murdered Jews corresponds to the image of God, who suffers. The other experience is contained in the poem of Kacenelson Pieśn o zamordowanym żydowskim narodzie, particularly in the song 9 Do niebios, where the poet, after the vehement accusations against "the heaven" breaks the Israel's covenant with God, and the murdered Jewish children take his place. The frame for comparison is the motif of transcendental tragedy, which originates as a result of the transformations of the antithetic images of God, combining in one schema of events, derived from the tragedy, the images of "God-tragedy", blamed for the disaster, and "tragic God", identified with the faultless suffering.

Keywords: faith, Holocaust, Warsaw ghetto, Icchak Kacenelson, Kalman Shapira

Streszczenie: Autor porównuje opisy dwóch przeciwstawnych doświadczeń religijnych, zrodzonych w okresie zagłady getta warszawskiego i dwóch związanych z nimi obrazów Boga. Jedno doświadczenie wyłania się z kazań konsolacyjnych rabina Kelmana Shapiry z Piaseczna, w których bezmiarowi cierpień mordowanych Żydów odpowiada obraz Boga, który cierpi. Drugie zawarte jest w poemacie Icchaka Kacenelsona Pieśn o zamordowanym żydowskim narodzie, a szczególnie pieśni 9, Do niebios, w której poeta po gwałtownych oskarżeniach „niebios” zrywa Przymierze Izraela z Bogiem, a jego miejsce zajmują pomordowane żydowskie dzieci. Ramą porównania jest figura tragiczności transcendentalnej, która po-

${ }^{1}$ Artykuł przygotowany do publikacji na podstawie referatu, wygłoszonego na otwartym seminarium naukowym „Wiara i niewiara. Literackie realizacje wobec doświadczenia Zagłady”, zorganizowanym przez Centrum Badań Holokaustu, Zakład Izraela i Lewantu Uniwersytetu Jagiellońskiego, Międzynarodowy Ośrodek Badań nad Historią i Dziedzictwem Kulturowym Żydów Europy Środkowej i Wschodniej, Pracownię Literatury Polsko-Żydowskiej Katolickiego Uniwersytetu Lubelskiego Jana Pawła II, 21-22.03.2017. 
wstaje jako wynik przekształceń antytetycznych obrazów Boga, łącząc w jednym zdarzeniowym schemacie, wywiedzionym z tragedii, obrazy „Boga tragedii” - obarczonego winą za nieszczęścia i „Boga tragicznego” - tożsamego z niezawinionym cierpieniem.

Słowa kluczowe: wiara, Holokaust, getto warszawskie, Icchak Kacenelson, Kalman Shapira

Chciałbym przedstawić niżej dwie odpowiedzi na dramatyczne pytania, wobec których stawała wiara Izraela w czasach Holokaustu. Pierwsza zawarta jest w kazaniach konsolacyjnych Kalmana Shapiry², rabbiego wspólnoty chasydzkiej w Piasecznie ${ }^{3}$, druga w znanym poemacie Pieśn o zamordowanym narodzie żydowskiem Icchaka Kacenelsona ${ }^{4}$.

Zanim jednak przejdę do samych obrazów zawartych w powyższych tekstach, chciałbym wstępnie określić ramy pojęciowe i interpretacyjne, w jakich zamierzam je przedstawić. Rama pojęciowa dotyczy kategorii wiary, ramę interpretacyjną zaś stanowi figura, którą nazywam figurą tragiczności transcendentalnej, wypracowana pod inspirującym wpływem hermeneutyki mitów tragicznych Paula Ricouera 5 .

\section{Wiara}

Wiarę będę rozumiał jako relację międzyosobową, w której jedna osoba obdarza drugą „zaufaniem”. W tym kontekście wiara wyraża się w formule: „wierzyć komus”, czyli „mieć do kogoś zaufanie”. Taka formuła zakłada,

${ }^{2} \mathrm{Z}$ dwóch funkcjonujących zapisów imienia i nazwiska rabbiego stosuję zapis powszechny w literaturze anglosaskiej: Kalman Shapira. Drugi zapis, stosowany częściej w literaturze polskiej (niezbyt licznej jak dotąd), Kalonymos Kalmisz Szapiro, stosuję w przytoczeniach.

${ }^{3}$ Rabbi Kalman Shapira zginął w obozie w Trawnikach w 1943 roku. Teksty jego sobotnich kazań głoszonych po hebrajsku między wrześniem 1939 roku a lipcem 1942 roku zostały odnalezione w ruinach getta warszawskiego w 1950 roku, a opublikowane w Izraelu w 1960 roku, Sefer Aish Kodesh, Vaad Hasidey, Piaseczno, Jerusalem 1960. (Na temat życia i działalności rabbiego Shapiry por. H. Abramson, Torah from the Years of Wrath 1939-1943: The Historical Context of the „Aish Kodesh”, New York 2017). Kazania, podobnie jak i sama postać rabbiego Shapiry, stały się szerzej znane dopiero po wydaniu przez Nehemię Polena książki poświęconej rabbiemu i jego kazaniom z czasów wojny (N. Polen, The Holy Fire: The Teachings of Rabbi Kalonymus Kalman Shapira, the Rebbe of the Warsaw Ghetto, New Jersey 1994) oraz po publikacji jego kazań w języku angielskim (K. Shapira, Sacred Fire: Torah from the Years of Fury, 1939-1942, transl. J.H. Worch, New Jersey, Jerusalem 2000).

${ }^{4}$ I. Kacenelson, Pieśń o zamordowanym żydowskim narodzie, tłum., wstęp, przypisy J. Ficowski, Warszawa 1986 (w nawiasach podaję numer pieśni).

5 P. Ricoeur, Symbolika zta, tłum. S. Cichowicz, M. Ochab, Warszawa 1986. Znacznie szerszą analizę tej kategorii znajdzie czytelnik w mej rozprawie W kręgu tragiczności: Księga Hioba. Fragment większego fragmentu, „Roczniki Humanistyczne” 2009, z. 1, s. 211-243.

${ }^{6}$ W kwestii kreślonego tutaj rozumienia wiary por. K. Rahner, H. Vorgrimler, Maty stownik teologiczny, tłum. T. Mieszkowski, P. Pachciarek, Warszawa 1996, hasło „wiara”; K. Rahner, O możliwości wiary dzisiaj, tłum. A. Morawska, Kraków 1983, s. 17-38. 
że osoba, do której mamy zaufanie, jest dla nas „wiary-godna”, czyli godna naszego zaufania. Wiarygodność to podstawa i warunek wiary. Tak rozumiana wiara może się ukonstytuować tylko w międzyosobowej sytuacji komunikacyjnej, w której osoba obdarzona zaufaniem potwierdza swoją wiarygodność. W odniesieniu do wiary w Boga sytuacja taka nazywa się objawieniem. Bóg staje w centrum wiary, kiedy jego przekaz jest wiarygodny, czyli budzi zaufanie. Odpowiedzią na wiarygodność Boga jest wierność tych, którzy obdarzają Go zaufaniem; wierność, czyli zobowiązanie do wytrwania w wierze nawet w okolicznościach, które mogłyby sugerować osłabienie wiarygodności boskiego przekazu, wytrwania „mimo wszystko”.

Nad tym podstawowym, komunikacyjnym wymiarem wiary nadbudowują się wymiary ontologiczne: ontologiczno-egzystencjalny, wyrażający się w formule „wierzę, że Bóg istnieje” albo krócej: „wierzę w Boga”; ontologiczno-materialny, gdy w wierze przyjmujemy pewne zasadnicze właściwości Boga, jak na przykład wszechmoc, niepojętość, sprawiedliwość, albo to, że Bóg jest miłością, oraz ontologiczo-formalny, gdy wyznajemy wiarę w jednego Boga, albo jednego Boga w trzech osobach.

W judaizmie - podkreślmy - podstawowa, komunikacyjna kategoria wiary jako zaufania, wiarygodności i wierności, ma charakter bardziej - niż na przykład w chrześcijaństwie - symetryczny i tym samym dialogiczny. Izrael ufa Bogu, ale i Bóg ufa Izraelowi, Izrael jest wierny Bogu, ale i Bóg jest wierny Izraelowi. Tak rozumiana symetryczność konstytuuje Przymierze między Bogiem i narodem Izraela, które jest podstawą i zasadniczą treścią religii żydowskiej.

Odpowiednio do powyższych rudymentarnych rozróżnień chciałbym poczynić kilka uwag wstępnych dotyczących sytuacji „utraty wiary” i tego, czym ona jest w odniesieniu do zarysowanych powyżej kategorii.

Po pierwsze, może się ona dokonać poza światem wiary, na przykład w świecie poznania: naukowego lub filozoficznego. Taki porządek utraty wiary nazwę ateistycznym, a jego zasadniczy kierunek przebiega od negacji wiary w sensie ontologiczo-egzystencjalnym (negacja wiary w istnienie Boga) do negacji wiary w sensie komunikacyjnym (objawionym) jako prostej konsekwencji pierwszej negacji. Ten rodzaj utraty wiary wiąże się z radykalnym opuszczeniem świata wiary.

Słabszą odmianą utraty wiary niż jej utrata w trybie ateistycznym jest tryb agnostyczny. Pierwszy zakłada negację wiary jako sąd o charakterze poznawczym oraz bardziej lub mniej aktywną postawę negującą porządek wiary i związaną z nią religię, drugi zasadza się na sceptycznym stosunku co do możliwości poznawczego rozstrzygnięcia kwestii wiary, biorąc w nawias całą sferę związanych z nią konsekwencji filozoficznych, społecznych oraz egzystencjalnych.

Po drugie, utrata wiary może się dokonać w przestrzeni samej wiary. W tym porząaku trzeba jednak naprzód rozróżnić między fenomenem utraty wiary a kryzysem wiary. Kryzys wiary, wywoływany przez różne czynniki i okoliczności, wiąże się z jakąś formą zwątpienia dotyczącego rozmaitych składników zarysowanego wyżej pojęcia wiary. Może dotyczyć samej wiarygodności 
boskiego objawienia albo jakichś dalszych aspektów wiary z nim związanych, na przykład ontologiczno-materialnych, przypomnijmy przykład Konrada, który wątpi w to, że Bóg jest miłością, czy ontologiczno-formalnych, by wspomnieć liczne formy schizmy, wynikające z różnokierunkowych transformacji pojęcia Boga i Trójcy Świętej w chrześcijaństwie.

Konsekwencje kryzysu wiary mogą być biegunowo różne. Pierwszy biegun negatywny - stanowi całkowita utrata wiary i przejście z porządku wiary do porządku ateistycznego lub agnostycznego. Drugi - jest utwierdzeniem w wierze, które dokonuje się w wyniku przezwyciężenia kryzysu. Między tymi biegunami istnieje wiele innych możliwości, takich jak konwersje międzywyznaniowe czy międzyreligijne, reformy religijne, religie prywatne, czy różne formy i stopnie obojętności religijnej.

Endlösung było przyczyną wielkiego, jeśli nie największego, jak twierdzą niektórzy, kryzysu wiary Izraela. Jaka była jego natura? Istnieje obszerna literatura poświęcona tym zagadnieniom, rozpatrywanym z bardzo różnych perspektyw, w tym także filozoficznej i teologicznej. Powstał wielki nurt problemowy teologii „po Szoa”, który daje odpowiedzi zarówno dramatyczne, jak i głębokie ${ }^{7}$. Na użytek tego tekstu chciałbym przyjąć następująca, dość oczywistą odpowiedź. Źródłem kryzysu wiary w okresie Holokaustu było wielkie, przekraczające wyobraźnię ludzką, niczym niezawinione cierpienie Izraela skazanego na zagładę i zamordowanego w trakcie Endlösung. W kontekście Przymierza cierpienie to zrodziło dramatyczne pytania o obecność, a w zasadzie nieobecność Boga w świecie Auschwitz i Treblinki. Czy Bóg nie widzi, że Izrael cierpi niewinnie, a jeśli widzi, to dlaczego milczy? Czy Bóg może być obojętny wobec cierpienia swego ludu? A jeśli jest obojętny, to czy nie zdradził w ten sposób Przymierza z nim? Jeśli cierpienie Izraela nie zostało zawinione ani wobec ludzi, ani wobec Boga, to jaki jest jego sens i czy ma ono jakikolwiek sens, czy jest wyłącznie absurdem? Oczywiście, kwestia wiary lub kryzysu wiary Izraela w okresie Zagłady jest niezwykle skomplikowana i wieloaspektowa. Nie da się jej przedstawić w jakichś prostych formułach. Mówimy przecież o sytuacji wielomilionowej społeczności religijnej, która została naprzód poddana nasilającym się represjom, a następnie w sposób systematyczny zamordowana. Wiedza czy może raczej nasze hipotezy i wyobrażenia na temat kryzysu wiary, jaki dotyczył członków tej społeczności, mogą być jedynie wyrywkowe i niekompletne, uzyskane na podstawie zachowanych świadectw i dokumentów. Paradoksalnie jednak, to właśnie indywidualne świadectwa, zwłaszcza te, które powstawały w trakcie procesów

$7 \mathrm{Z}$ obszernej literatury przywołuje jedynie kilka publikacji: Dialogue at the Edge of Auschwitz-Perspectives for a Theology after Auschwitz, Kraków, Oświęcim 2014 (zawiera głosy polskie, żydowskie i niemieckie); Teologia i filozofia żydowska wobec Holocaustu, wstęp, wyb., oprac. P. Śpiewak, Gdańsk 2013; Holokaust a teodycea, red. J. Diatłowicki, K. Rąb, I. Sobieraj, Kraków 2008; A. Zuberbier, Teologia katolicka po Holokauście, „Znak” 1996, nr 3, s. 62 - 67; H. Jonas, Idea Boga po Auschwitz, tłum. G. Sowinski, Kraków 2003; R. Rubenstein, After Auschwitz. Radical Theology and Contemporary Judaism, New York 1966. 
eksterminacyjnych, właśnie dlatego, że dają wgląd w wewnętrzne doświadczenia wiary lub jej kryzysu, mogą pozwolić na uogólnienie tej kwestii w odniesieniu do całej poddanej eksterminacji społeczności, szczególnie jeśli mamy do czynienia ze świadectwami osób o głębokiej i ugruntowanej wierze religijnej, a takimi są autorzy przywołanych tekstów, rabbi Shapira i poeta Kacenelson.

Mówiąc o kryzysie wiary, zawężam jego rozumienie do pewnego tylko aspektu, mianowicie do intencjonalnego obrazu Boga, jaki wyłania się nie tylko z wiary religijnej rozumianej jako objawienie, ale także z rozwinięcia jej w wykładniach teologicznych. Nie chodzi tu o zmysłowy obraz będący przedstawieniem Boga, w judaizmie, jak wiemy, opatrzony zakazem, ale o pewien pojęciowo-wyobrażeniowy model Boga osobowego, powstały przez rzutowanie przypisanych mu przez objawienie właściwości na osobowe cechy ludzkie. Powstały w ten sposób wizerunek pozwala ustanowić między człowiekiem i Bogiem komunikacyjną relację osobową. Obraz czy obrazy tak rozumiane podlegają w dziejach religii różnym korektom i przemianom. Bywają sytuacje, w których obraz Boga wiary niejako nie wytrzymuje doświadczenia wiary. Przykładem niech będzie to opisane w Księdze Hioba. Gwałtowna obrona własnej niewinności dotkniętego nieszczęściami Hioba prowadzi w konsekwencji do rozszczepienia obrazu Boga wiary na Boga, którego Hiob oskarża o okrucieństwo i niesprawiedliwość, oraz przywołanego przez sprawiedliwego męża „obrońcy w niebie” (go’el), który stanie po stronie jego nieszczęść, poświadczając ich niezawiniony charakter.

\section{Figura tragiczności transcendentalnej}

Przywołuję Księgę Hioba nie bez przyczyny. Rozszczepienie obrazu Boga, o jakim przed chwilą wspomniałem, łączy się właśnie z figurą tragiczności transcendentalnej. Otwiera ono bowiem możliwość przekształceń scalających rozbieżne obrazy w schematach tragiczności transcendentalnej - opartej na podobnej do greckiej figurze przemieszczenia.

Tragicznością transcendentalną nazywam zatem złożoną figurę interpretacyjną opartą na rozszczepieniu, a następnie połączeniu relacją tożsamości dwóch antytetycznych obrazów Boga: Boga sprawcy tragicznego nieszczęścia (Boga tragedii) z obrazem Boga, który staje po stronie ludzkiego nieszczęścia i cierpienia, sam ich doznając (Boga tragicznego).

Pierwszym źródłem strukturalnym dla tak rozumianej figury jest, z jednej strony, schemat zdarzeniowy greckiej tragedii przeznaczenia, opartej na autotelicznym przemieszczeniu bohatera z pozycji podmiotu działającego - rodzącego zło tragiczne i winę tragiczną - na pozycje podmiotu doznającego tego działania. Przemieszczenie to „egzystencjalizuje” winę moralną działań bohatera tragicznego, nadając jej postać winy tragicznej, wyrażającej się w ambiwalencji winy i niewinności, co widać zwłaszcza na przykładzie tragizmu Edypa. 
Istota figury tragicznego zła wyraża się w tym, że jest ono jako element sprawczy tragicznej winy ściśle powiązane z elementem doznawania zła. Grecka tragedia nadała temu powiązaniu charakter uniwersalny, łącząc oba elementy w osobie tego samego bohatera. Historia rodzenia się zła i historia jego doznawania zostały tym samym splecione w jednym, obejmującym oba te elementy, doświadczeniu jednego i tego samego podmiotu - bohatera tragicznego.

Drugim i zasadniczym źródłem tragiczności transcendentalnej są księgi biblijne: Hioba i Izajasza. Istotna jest tu formuła interpretacyjna Ricouera, dotycząca motywu go’el z Księgi Hioba wyrażona w słowach: „To Boga przyzywa Job przeciwko Bogu”, rozszczepiająca obraz Boga ${ }^{8}$. Ich waga transformacyjna polega na otwarciu możliwości przemieszczenia pozycji Boga $\mathrm{w}$ schemacie tragicznego mythos, a w rezultacie na ukonstytuowaniu się obrazu Boga, który staje po stronie ludzkiego nieszczęścia, zrazu jako świadek i poręczyciel braku przewiny, która miałaby uzasadniać nieszczęście Hioba, a w dalszych transformacjach (które odnajdujemy w innych tekstach biblijnych, zwłaszcza u Izajasza, oraz ich interpretacjach, a także w tekstach współczesnych) z nieszczęściem tym się w szczególny sposób utożsamia, sam go doznając.

To właśnie owo rozszczepienie obrazu Boga, a następnie przemieszczenie analogiczne do jednopodmiotowej struktury przemieszczenia $\mathrm{w}$ tragediach greckich, mam na myśli, mówiąc o tragiczności transcendentalnej. Przy czym samo pojęcie tragiczności, o którym tu mowa, zakłada określony charakter i kierunek transformacji i scalenia obrazu Boga. Jest to kierunek, należy podkreślić, w którym samo rozszczepienie obrazu Boga i przemieszczenie go z podmiotu działającego na pozycje podmiotu doznającego nie jest wystarczające. Konieczne staje się jeszcze wyodrębnienie i połączenie dwóch planów doświadczenia - doświadczenia boskiego i doświadczenia ludzkiego. Dopiero relacja tożsamości, łącząca oba te plany: plan obrazu Boga działającego i plan ludzkiego doświadczenia tragicznego nieszczęścia, tworzy pełną figurę tragiczności transcendentalnej.

$\mathrm{Z}$ tego punktu widzenia szczególnie ważnym źródłem biblijnym tragiczności transcendentalnej jest Księga Izajasza, a zwłaszcza jeden motyw, drobny w sensie objętościowym, wzbudzający kontrowersje i filologiczne, i teologiczne, ale niezwykle ważny strukturalnie. Ustanawia się w nim taka relacja między Sługą Pańskim a Bogiem, którą można ująć analogicznie do relacji widocznej w motywie doświadczenia Hioba przez Boga, a mówiąc jeszcze inaczej, motyw Sługi zostaje włączony w schemat działania Boga. Chodzi tu o wers 10. z 53. rozdziału: „Spodobało się Panu zmiażdżyć Go cierpieniem”. Motyw ten, który teologicznie interpretuje się jako „włączenie w plan Boga”, wytwarza pewne

${ }^{8}$ P. Ricoeur, dz. cyt., s. 302, por. także R.E. Murphy, Księga Hioba, tłum. H. Bednarek [w:] Międzynarodowy komentarz do Pisma Świętego, red. W.R. Farmer, Warszawa 2001, s. 664.

${ }^{9}$ Cytaty z Pisma Świętego według wyd. 4 Biblii Tysiąclecia, oprac. Zespół Papieskiego Wydziału Teologicznego w Poznaniu, Poznań 1998, http://biblia.deon.pl/, dostęp: 4.07.2018. 
napięcie w stosunku do bardziej wyraźnego motywu poświęcenia („sam się obarczył naszym cierpieniem", w. 4a), interpretowanego jako dobrowolna realizacja tego planu ${ }^{10}$. Waga ustanowionej przez ten motyw relacji polega na rysującej się możliwości przekształcenia jej w relację autoteliczną, która jest podstawowym czynnikiem przemieszczającym w schemacie tragiczności transcendentalnej.

Chodzi tu jednak także o coś więcej, mianowicie o szczególne napięcia tożsamościowe, które w wypadku Księgi Hioba ujawniły się jako problem interpretacji motywu go'el, utożsamiającej go z Bogiem. W Księdze Izajasza owe napięcia tożsamościowe występują z nieporównanie większą siłą w przypadku interpretacji chrystologicznej czy nawet mesjańskiej i łączą - by tak powiedzieć - elementy z różnych poziomów. Napięcie tożsamościowe w Księdze Hioba ustanawia się między adresatem skargi „męża sprawiedliwego” a przywołanym przez niego „obrońcą w niebie”, w Księdze Izajasza zaś ustanawia się ono - interpretacyjnie - między „Panem” a "Cierpiącym Sługą”, przez co relacja tożsamościowa staje się nieporównanie bardziej skomplikowana, łącząc boski poziom zdarzeń z ludzkim. W interpretacji chrześcijańskiej stanowi ona podstawę prefiguracji utożsamiającej „Sługę Pańskiego” z Chrystusem, a tym samym ustanawia relację tożsamości między Bogiem działającym (Panem) a doświadczającym zmiażdżenia człowiekiem (Sługa).

Przejście od tożsamościowej relacji z Księgi Hioba ustalającej się na poziomie rozszczepienia obrazu Boga do tożsamościowej relacji z Księgi Izajasza, ustalającej się na poziomie obrazu Boga i cierpiącego człowieka, innymi słowy, przejście od mało wyrazistego motywu „obrońcy w niebie” (go’el) do jednego z najbardziej przejmujących poetyckich obrazów ludzkiego cierpienia, które $\mathrm{w}$ planie horyzontalnej interpretacji utożsamia się z cierpieniem Boga, wyznacza kierunek transformacji schematu tragiczności transcendentalnej.

Zarazem pokazuje, jak skomplikowany i napięty charakter ma formuła autoteliczna („Spodobało się Panu zmiażdżyć Go cierpieniem”) uruchomiona przez tę Księgę. Pomijam tu wykładnię teologiczną wiążącą się z relacją tożsamościową „Cierpiącego Sługi” i jego figuralnym sensem, stanowi ona podstawę centralnej dla chrześcijaństwa tajemnicy wiary. W mojej wykładni tej figury, co chciałbym podkreślić, chodzi wyłącznie o fenomenologiczną analizę strukturalnie powiązanych obrazów i towarzyszących im formuł wydarzeniowych.

10 A.-M. Pelletier, Księga Izajasza [w:] Międzynarodowy komentarz do Pisma Świętego, dz. cyt., s. 874. Nie jest przy tym bez znaczenia, że dysponujemy w tym wypadku dwiema tradycjami hermeneutycznymi: hebrajską i chrześcijańską. Jeśli ta ostatnia - jak powiada współczesny komentator - „od samego początku sytuuje tę wyrocznię w centrum wyznania wiary, rozumiejąc ją w sensie jednostkowym i wyjaśniając ją wyłącznie w świetle męki i zmartwychwstania Jezusa" (tamże, s. 875), to wykładnia żydowska widzi w Słudze Pańskim bądź figurę mąk doznawanych przez Izrael na wygnaniu, bądź posłannictwo Izraela polegające na dźwiganiu przezeń grzechów świata i w ten sposób umożliwiające światu dalsze trwanie (tamże). O tym, że owa ostatnia interpretacja może zostać rozwinięta w schemacie tragiczności transcendentalnej i ukonstytuować obraz Boga tragicznego, świadczy poemat Kacenelsona. 
Powiązanie obrazu Boga, „któremu spodobało się zmiażdżyć Go cierpieniem”, z obrazem Sługi, który w interpretacji chrześcijańskiej staje się figurą Chrystusa-Pana, przez połączenie dwóch poziomów: boskiego i ludzkiego ustanawia nie co innego, jak pełną figurę tragiczności transcendentalnej.

Kierunek przekształceń obrazów Boga w tragiczności transcendentalnej jest wyraźny. Są to przekształcenia idące „w dół”, schodzące „nisko” - jakby powiedział Herbertowski Pan Cogito - od obrazu Boga radykalnie transcendentnego wobec świata, doskonałego i niedostępnego władcy, do obrazów Boga osłabionego, poddanego przewadze świata, miażdżonego cierpieniem, popadającego w tragiczne nieszczęście i dalej, od mistycznych obrazów Boga cierpiącego na sposób boski - niedostępny ludzkiej wrażliwości - do obrazów cierpienia tożsamego z cierpieniem ludzkim. Innymi słowy, jest to przejście od nieludzkiego do ludzkiego, od obrazu Boga zgrozy do obrazu Boga niewinnie cierpiącego, czy to na sposób boski, czy ludzki. Jednocześnie trzeba podkreślić, że pełna figura tragiczności transcendentalnej łączy te antytetyczne obrazy w jedną całość, w której napięcie tożsamościowe między członem pierwszym a ostatnim jest nieusuwalne. Można powiedzieć, że pełna figura tragiczności transcendentalnej w jakimś stopniu definiuje wewnętrzny konflikt rozwiniętej postaci monoteistycznej wiary.

\section{Bóg cierpiący rabbiego Shapiry}

Dramatyczny i poruszający obraz Boga cierpiącego odnajdujemy w kazaniach rabbiego wspólnoty chasydzkiej w Piasecznie i założyciela chasydzkiej uczelni w Warszawie Kalmana Shapiry, głoszonych po hebrajsku w Warszawie w latach 1939-1942 ${ }^{11}$. Przywołajmy na początek słowa autora wstępu do polskiego tłumaczenia kazań:

W kazaniach z czasów wojny Kalonymos Szapira wielokrotnie porusza problem cierpienia. Na początku ujmuje je w tradycyjny sposób: cierpienie przynosi odpuszczenie grzechów, jest środkiem oczyszczenia i uświęcenia człowieka. W późniejszym okresie zaczyna kłaść nacisk na cierpienie Boga. Cierpiący Żyd może sądzić, że tylko on cierpi, a cierpienia całego narodu nie dotyczą Boga. Jednak jak mówi Izajasz $(63,9)$ - „I stał się dla nich wybawicielem w każdym ich ucisku”. Dlatego też, kiedy człowiek cierpi, wraz z nim cierpi i Bóg. (...) W czasach Zagłady tradycyjne uzasadnienia cierpienia przestały mieć sens - potrzebne było

${ }^{11}$ Teksty kazań cytuję na podstawie następujących przekładów: Rabbi K. K. Szapira, Święty ogień. Tora z lat 1939-1942, lat szatu, wyb., wstęp W. Mędykowski, tłum. I. Kania, „Znak” 2006, nr 4, s. 58-110; P. Śpiewak, Kaznodzieja getta warszawskiego, „Znak” 1996, nr 3, s. 120-130; Taniec opowiésci, czyli chasydzi Piaseczna, www.studnia.org/piaseczno.ramka.htm, dostęp: 13.09.2018. Materiał o rabbim opracowany przez Włodzimierza Bagieńskiego i Piotra Rytka - w zakładce Cadyk Piaseczna. 
nowe. Kalonymos dowodzi zatem, że to nie grzech jest przyczyną cierpienia. Zagłada to konsekwencja ataku na samego Boga, a synowie Izraela cierpią wraz z nim. W czasach ukrycia swojej twarzy Bóg płacze, a Żyd płacze wraz z nim² ${ }^{12}$.

Ukonstytuowanie obrazu Boga cierpiącego (płaczącego) - szczególnie w części późnych kazań, zatytułowanej przez rabbiego Kidusz ha-Szem - przebiega (w sensie strukturalnym) w trzech etapach. Po pierwsze, następuje odróżnienie cierpienia Boga od cierpienia ludzkiego. Różni się ono od ludzkiego skalą, która jest nie do ogarnięcia przez człowieka, co zarazem tłumaczy w jakiś sposób „milczenie Boga”:

Bóg cierpi więcej niż jakikolwiek człowiek. Ponieważ Bóg jest nieskończony, Jego ból, spowodowany cierpieniem Jego stworzeń, jest nieskończony, żaden poszczególny człowiek nie może znieść ani pojąć bólu Boga (...). Gdyby świat podzielił całe cierpienie Boga, to by nie mógł go wytrzymać. Gdyby stworzenie Boże usłyszało dźwięk Bożego płaczu, to cały świat by się rozpadł (14 lutego 1942) ${ }^{13}$.

Towarzyszy temu, po drugie, nawiązujące do mistycznego motywu „komnat bożych", zróżnicowanie obrazu Boga, szczególne jego rozszczepienie na dwa obrazy: Boga „mocy i dostojeństwa” oraz Boga płaczącego:

Dowiadujemy się więc, że podczas gdy w zewnętrznych komnatach nieba zawsze są przed Bogiem „moc i dostojeństwo”, w komnatach wewnętrznych Bóg płacze zgnębiony, by tak rzec, cierpieniami Żydów ${ }^{14}$.

W trzecim kroku rabbi wyjaśnia sens (konsolacyjny) współcierpienia człowieka i Boga:

Jak jednak powiedzieliśmy wyżej, w komnatach wewnętrznych płacze sam Święty Błogosławiony, a każdy, kto przywiera do Boga poprzez Torę, może tam płakać razem z Nim oraz studiować Torę razem z Nim. Różnica jest taka. Udręka i zgryzota, jakie człowiek w samotności cierpi z powodu własnego położenia, mogą go złamać. Może tak pod nimi upaść, że nieruchomieje. Ale wspólny płacz z Bogiem daje człowiekowi siłę. On płacze i nabiera siły. Wstrząsa nim to, lecz następnie nabiera śmiałości do studiów i oddawania czci Bogu ${ }^{15}$.

Nie tu miejsce na dokładniejszą analizę tych niezwykłych obrazów, wywiedzionych z głębokich pokładów mistyki żydowskiej. Zadowolić się musimy

12 W. Mędykowski, Wstęp [do:] Rabbi Kalonymos Kalmisz Szapira, dz. cyt., s. 60 i nn.

13 Taniec opowieści..., dz. cyt.

${ }_{14}$ Rabbi Kalonymos Kalmisz Szapira, dz. cyt., s. 99.

15 Tamże, s. 100. 
jedynie stwierdzeniami dotyczącymi ich zasadniczej struktury. Znamienna jest także dynamika rozwoju tego obrazu, który wyłania się z napięcia między figurą „,boskiej niepojętości”, do której odniesione zostają przez rabbiego ciężkie doświadczenia Izraela, a figurą boskiego ocalenia - ocalenia, w które Żydom coraz trudniej pokładać nadzieję. Kiedy udręki stają się bezgraniczne i nie do udźwignięcia przez wiarę Żydów i kiedy pojawia się przeświadczenie o niezawinionym cierpieniu („Izrael jest niewinny”), wtedy rabbi Shapira w cyklu kazań konsolacyjnych rysuje mesjański obraz Boga biorącego na siebie nieszczęścia swego ludu i w ukryciu przed światem płaczącego nad cierpieniami Izraela:

Bywają czasy, jakie opisują słowa „Będę z nim w utrapieniu” (Ps 91,15). W takich czasach udręki, Boże broń, spadają na Izrael, a Bóg po prostu cierpi z nami, ale gdy udręki są tak wielkie, że Izraelowi brak sił, by je znieść, wtedy jedynie Bóg daje nam siły, aby przetrwać i przeżyć te gorzkie i okrutne nieszczęścia - wówczas ciężar spada na Niego. Wynika z tego, że w czasach, gdy nieszczęścia nie są jeszcze tak wielkie (...), nadal można rozważać, czy jesteśmy warci w oczach sprawiedliwości, ale gdy udręki są tak wielkie, Boże, ocal nas, iż ich ciężar spada na Boga, wtedy niebiosa muszą ruszyć na pomoc. Izrael jest niewinny, więc dlaczego nasz Ojciec w niebie miałby cierpieć ${ }^{16}$.

Analizując mesjańskie obrazy współcierpienia Izraela i Boga, Paweł Śpiewak pisze:

W tym akcie narodzin nowego objawienia Bóg nie jest oddalonym świadkiem czy jedynym sprawcą wydarzeń. Bóg uczestniczy w „bólu porodowym” [Mesjasza - A.T.], w cierpieniu Izraela, cierpiąc wraz z nim zamknięty w Wewnętrznej Komnacie Niebios (motyw zaczerpnięty z dawnej literatury żydowskiej). Bóg skrywa się tam, ponieważ Jego cierpienia, jak i on sam są nieskończone. Bóg ma bowiem dwie komnaty: zewnętrzną, gdzie pojawia się radosny i zadowolony, i komnatę wewnętrzną, która skrywa jego tajemnicę i gdzie z racji swej dumy ukrywa się, by płakać w samotności i przeżywać nieskończony ból. Można rzec, że w tym cierpieniu Boga i Izraela trwa dawne przymierze, wspótczucie Boga dla Izraela i Izraela dla Boga, trwa wspólnota w cierpieniu. Jego milczenie i nieobecność są tylko pozorne. Odwraca swe oblicze, by jego niezmierzone cierpienie nie rozsadziło świata ${ }^{17}$.

Podsumujmy ten krótki wgląd w dzieło rabbiego z Piaseczna. W obrazie kreślonym przez niego odnajdujemy trzy elementy konstytutywne: 1. skala płaczu, 2. odróżnienie komnat zewnętrznych od komnat wewnętrznych oraz 3. sens relacji współcierpienia człowieka i Boga. Elementem transformacyjnym w myśl reguł tragiczności transcendentalnej jest tu element drugi, jego

\footnotetext{
16 P. Śpiewak, dz. cyt., s. 127.

17 Tamże, s. 128.
} 
funkcja polega na przemieszczeniu Boga z komnat zewnętrznych, w których odznacza się On „mocą i dostojeństwem”, do wewnętrznych komnat płaczu będącego wyrazem boskiego cierpienia, a tym samym ustanowieniu dwóch boskich „wizerunków”. To obrazy Boga „mocy i dostojeństwa” oraz Boga płaczu, który współcierpi z człowiekiem, dając mu siłę, by nie upaść i „znieruchomieć” w sytuacji, w której Bóg „mocy i dostojeństwa” nie udziela odpowiedzi na najbardziej palące pytania cierpiącego niewinnie Izraela.

Znamienną cechą mistycznego wizerunku „Boga cierpiącego” jest całkowita transcendentność cierpienia Boga wobec cierpienia ludzkiego. Bóg cierpi skrycie na sposób i miarę boską, a nie ludzką. Nie jest to obraz oparty na relacji tożsamościowej, łączącej poziom boski z ludzkim doświadczeniem, a jedynie na korygującym rozszczepieniu obrazu Boga wyłącznie na poziomie boskim i w tym znaczeniu nie jest pełną figurą „tragiczności transcendentalnej”, która takie połączenie poziomów boskiego z ludzkim zakłada. Waga transformacyjna obrazu kreślonego przez rabbiego polega na możliwości wprowadzenia do pojęciowo-wyobrażeniowego modelu Boga osobowego nie tylko rozjaśniających boską skrytość analogonów cech ludzkich, takich jak sprawiedliwość, wszechmoc, wszechwiedza, miłosierdzie, doskonałość, które tworzą wizerunek Boga „mocy i dostojeństwa", lecz także analogonu ludzkiego doświadczenia łączonego ze słabością, kruchością i niedoskonałością istnienia, a nade wszystko z byciem ofiarą przemocy i „przeznaczeniem na zagładę”. Cierpiący Bóg Kalmana Shapiry wydaje się przywracać gasnącą wiarygodność Boga Izraela. Paradoksalnie w sytuacji kryzysu wiary, spowodowanego cierpieniem nie do zniesienia i gasnącą nadzieją na ocalenie, ten właśnie obraz Boga - osłabionego cierpieniem - niósł pocieszenie przeznaczonej na zagładę społeczności. Konsolacja miała tu charakter włączenia Boga - jak to ujął Paweł Śpiewak - do „wspólnoty w cierpieniu” ${ }^{18}$ i tym samym podtrzymania Przymierza opartego na obustronnym współczuciu.

\section{„Niebiosa puste” Kacenelsona}

Poemat Icchaka Kacenelsona Dos lid fun ojsgehargeten jidiszen fotk, przetłumaczony na język polski przez Jerzego Ficowskiego (Pieśn o zamordowanym żydowskim narodzie ${ }^{19}$, to przejmujące świadectwo zagłady warszawskiego getta, a zarazem wielka poetycka skarga wyrastająca $\mathrm{z}$ tragicznego doświadczenia autora poematu, jego rodziny i całej społeczności polskich Żydów. Polski tłumacz poematu pisze: „Icchak Kacenelson zdobył się na heroizm słowa ostatecznego i pozostawił światu świadectwo - jakże bliskie wydrapywanym na ścianach cel śmierci ostatnim słowom skazanych, a zarazem - ślad będący dziełem sztuki”20.

\footnotetext{
18 Tamże.

19 I. Kacenelson, dz. cyt.

${ }^{20}$ J. Ficowski, Wstęp [w:] I. Kacenelson, dz. cyt., s. 8.
} 
Poeta $\mathrm{w}$ wielkiej akcji likwidacyjnej getta warszawskiego przeżył utratę żony i dwóch młodszych synów. Sam był uczestnikiem powstania w getcie oraz świadkiem ostatecznej jego likwidacji. Deportowany wraz z najstarszym synem do obozów we Francji, a następnie do Auschwitz zginął na początku maja 1944 roku. W tym czasie, „odroczonej na krótko” zagłady, powstaje w obozach Francji poemat, który cudem przetrwa śmierć autora, zostanie odnaleziony i opublikowany po wojnie.

Struktura poematu jest artystycznie przemyślana i konsekwentna ${ }^{21}$. Na utwór składa się piętnaście tytułowanych pieśni, każda zbudowana z piętnastu strof. Przeważają strofy czterowersowe, ale są też pieśni zbudowane z oktaw lub sestyn. Charakterystyczna jest rama kompozycyjna wyznaczona przez precyzyjnie skonstruowaną sytuację liryczno-narracyjną i nawiązującą do psalmów stylizację podmiotu lirycznego na pieśniarza śpiewającego przy akompaniamencie harfy (p. I). Poemat staje się głosem ostatniego żydowskiego poety, przed którym staje zadanie zaśpiewania o "ginących ostatnich Żydach w Europie” (p. I). Zadanie tragicznie beznadziejne, bowiem Żydów już nie ma. Jedynie siłą wizji poetyckiej twórca przywołuje cały wymordowany naród (p. I i II), by następnie w kolejnych pieśniach, przypomniawszy z różnej perspektywy tragiczne wydarzenia $\mathrm{z}$ getta warszawskiego, a także paralelne wydarzenia z dziejów Przymierza, w tonacji tragicznego żalu i rozpaczy, definitywnie zamknąć historię narodu żydowskiego liczoną od Pięcioksięgu „do dziš”, „Od Amaleka po Niemców” (p. XV):

Biada mi! Nie ma nikogo... Był kiedyś naród, był naród

I już go nie ma na ziemi... Skończone... Koniec już, wiem to!

To była taka opowieść - ongi Pięcioksiąg ją począt,

Trwała do dziś... bardzo smutna. I któż by nazwał ją piękną?

(p. XV, Po wszystkim)

W sensie genologicznym poemat ma charakter lamentacji, nawiązującej w jakiejś mierze do lamentacji starotestamentowych, a także - przez precyzyjny układ części i ich następstwo, z dominującym tonem rozpamiętywania, żalu i rozpaczy po stracie bliskich i całego własnego narodu - do cyklu trenicznego, pozbawionego jednakże elementów konsolacyjnych. Rozpacz i dojmujące uczucie osamotnienia to zasadnicze jakości wieńczące emocyjną strukturę poematu. Bohaterem cyklu jest naród żydowski zamordowany w trakcie Endlösung, przywołany przez poetę $\mathrm{w}$ dwóch pierwszych pieśniach, paralelnych do wizji

${ }^{21}$ Jeśli pominie się wstęp Ficowskiego do tłumaczenia Pieśni, to istnieją w literaturze polskiej dwie analizy poematu Kacenelsona, całościowa: A. Pawelec, M. Sitarz, Ostatni Żyd w Europie, „Pieśn o zamordowanym żydowskim narodzie” Jicchoka Kacenelsona, „Zeszyty Naukowe Centrum Badań im. Edyty Stein” 2014, nr 12, s. 203-220 oraz moja, poświęcona pieśni IX zatytułowanej Do niebios: A. Tyszczyk, „Do niebios” Icchaka Kacenelsona [w:] Literatura polsko-żydowska. Studia i szkice, red. E. Prokop-Janiec, S.J. Żurek, Kraków 2011, s. 145-154. 
prorockich, a następnie spersonalizowany w różnego rodzaju odniesieniach, zarówno osobistych (rodzina), jak i obejmujących różne kręgi społeczności Żydów polskich, w końcu narodu żydowskiego całej Europy. Ton osobisty i osobisty dramat poety jest tu, odmiennie niż na przykład w cyklu Jana Kochanowskiego, ważną, ale nie jedyną jakością elegijną, splata się nierozerwalnie z tragedią dziejową „okrutnie ukrzyżowanego” Izraela, chociaż to właśnie doświadczenie osobiste przydaje strukturze emocyjnej utworu niezwykłej siły.

$\mathrm{Na}$ tę ogólną strukturę nakładają się odniesienia biblijne, zarówno jako pewnego rodzaju analogony do dziejów Przymierza, jak i elementy konstrukcji lirycznej, jak na przykład psalmiczność lamentacyjna i złorzecząca w niektórych pieśniach, formy skargi, nawiązujące do Księgi Hioba czy tony prorockie.

Wyraźny jest też szczególny paralelizm między nieszczęściami biblijnymi Izraela a jego losem w XX wieku. Ma on ukazać ogrom nieszczęść spadających na Żydów, przewyższających niepomiernie skalę doświadczeń biblijnych. Już w II pieśni, ewokującej wizję zamordowanego narodu, poeta nawiązuje do Ezechiela $(\mathrm{Ez}, 37)$ i doliny wypełnionej kośćmi Izraela, które Bóg obiecuje wskrzesić, przyoblec w ciało i tchnąć w nie ducha. Tłum zamordowanych $\dot{Z} y-$ dów, który staje w milczeniu przy poecie, przywołany jego pieśnią, jest nieporównanie większy od tego z wizji proroka, ale i stopień fizycznego unicestwienia przewyższa obraz biblijny: „nawet nie pozostały kości, nie ma już czego przyoblec w ciało (...) w co można znowu tchnąć ducha” (p. II).

Temu mierzeniu się z dziejami nieszczęść Izraela odpowiada mierzenie się z Jego Bogiem. Nawiązania są liczne, ale centralne miejsce zajmuje pieśń IX zatytułowana Do niebios. Można ją czytać jako radykalny wariant psalmu złorzeczącego, $\mathrm{z}$ tą poprawka, że przedmiotem urągania staje się sam Bóg. Zawarte w niej oskarżenie niebios, stanowiące powód złorzeczenia, rozwija się od argumentów moralnych, skrupiających się w formule „niegodnego oszukania”, a kończy na negacji ontologicznej („Niebiosa puste”). Teologicznie rzecz wydaje się rozstrzygnięta.

W istocie taka konkluzja jest pozorna. „Niebiosa puste” nie oznaczają porzucenia transcendencji i świętości, nie jest to ani negacja ateistyczna, ani agnostyczna, nie jest związana z poznaniem, lecz doświadczeniem bólu i cierpienia Izraela. Wiedzie w konsekwencji do zerwania Przymierza, bowiem „Bóg niebios” oszukał swój naród, stając po stronie prześladowców. Endlösung odsłania przed poetą oblicze Boga zgrozy i jako taki Bóg ten zostaje zanegowany. Pozostaje "puste miejsce”, owo centrum boskiej transcendencji. Może je wypełnić tylko doświadczenie najczystszego bólu Izraela.

W kontekście figury tragiczności transcendentalnej tak rozumiana negacja jest wynikiem ciśnienia, które rozsadza obraz Boga wiary, sytuując go po stronie sprawców tragedii. $Z$ drugiej strony poeta szuka możliwości zastąpienia obrazu „zgubionego w niebiosach Boga” wizją boskości, która sama doświadcza tragicznego nieszczęścia. Jeśli „normą” boskości staje się - jak w chrześcijańskiej interpretacji Izajaszowego Sługi - przyjęcie niezawinionego cierpienia, to normę tę spełniają jednostki zarazem najsłabsze, jak i z istoty całkowicie 
niewinne - idące na zagładę żydowskie dzieci. „Każde z mych dzieci zgładzonych mogłoby stać się Bogiem" - woła poeta, rysując obraz wniebowstąpienia zamordowanych żydowskich dzieci i całego narodu „okrutnie ukrzyżowanego”:

Nie ma was Boga! Więc rozewrzyjcie na oścież swoje niebieskie bramy,

Niech wszystkie dzieci zamęczonego narodu ruszą w ostatnią drogę.

Wniebowstąpienie! Niech wnijdzie do was naród okrutnie ukrzyżowany,

Otwórzcie wrota!... Każde z mych dzieci zgładzonych mogłoby stać się Bogiem!

(p. IX Do niebios)

Pamięć utraconych dzieci, dzieci własnych i męczeństwa wszystkich dzieci żydowskich, jest źródłem największego bólu. One Pierwsze, tak zatytułował pieśn w całości poświęconą męczeństwu dzieci z getta warszawskiego. Pierwsze na Umschlagplatz szły dzieci z sierocińców, najsłabsze. Pojawiają się więc motywy dzieciństwa ogołoconego przez wojnę z relacji rodzinnych oraz bezdomności i całkowitej bezbronności wobec przemocy. Najsłabsze, najbardziej niewinne, całkowicie bezbronne, osierocone. Nie można zejść już niżej w obrazie okrucieństwa zbrodni. Kacenelson zna dzieci z przytułków i domów sierot, dla których pisał sztuki. Przywołuje je we wspomnianej pieśni oraz w wielu innych miejscach. I w tych właśnie obrazach dzieci z sierocińca natrafić można na motyw, który staje się kluczowy dla zrozumienia funkcji postaci dzieci w całym poemacie. To kwestia szczególnej ich dojrzałości i mądrości, która w przestrzeni tragedii przewyższa nie tylko mądrość dorosłych, ale także całą mądrość Izraela, łącznie z mądrością proroków, a kulminuje w ich mesjańskim wywyższeniu i uświęceniu - „święte mesjasze krwią uświęcone" - jak je nazwie 22 .

O, nie! Obszary całej Europy. O miasta wszystkie, słuchajcie o nich! Czegoś takiego nie znał świat jeszcze, tego nie widział nikt na tej ziemi!

To one pierwsze miały umierać - żydowskie dzieci, te smutnookie,

Osierocone, zimnem przeżarte, głodem i wszami. To One. Za co?

Święte Mesjasze krwią uświęcone...

$$
\text { (p. VI One pierwsze) }
$$

Jest rzeczą zrozumiałą, że tak rozwijający się schemat tragiczności transcendentalnej musi wytworzyć potężne napięcia tożsamościowe, wzmocnione dodatkowo strukturalną ambiwalencją ofiarniczej sakralizacji. Chodzi przede

${ }^{22}$ Interesujące byłoby porównanie obrazu dzieci żydowskich z warszawskiego getta kreślonego przez Kacenelsona z obrazem, jaki daje, szczególnie w Pamiętniku i innych pismach z getta, Janusz Korczak. Jeśli u Kacenelsona uświęcająca mądrość i dojrzałość dzieci tworzą pozytywnie i sakralnie nacechowaną postać toposu dziecka-starca, to u Korczaka ten sam topos ma nacechowanie negatywne, ukazuje udrękę, zniedołężnienie i zobojętnienie dzieci poddanych okrutnym warunkom życia i traumatycznym doświadczeniom, w jakimś sensie jest to obraz analogiczny chyba tylko do opisu „muzułmanizmu” obozowego autorstwa Brunona Bettelheima. 
wszystkim o napięcia między obrazem Boga „zgubionego w niebiosach”, a wizją niewinnych ofiar zajmujących „puste” miejsce w „niebie”, innymi słowy, chodzi o napięcia tożsamościowe między Bogiem żydowskiej teologii a poetyckim obrazem Boga tragicznego, zintensyfikowane jeszcze przez mesjański kontekst z jednej strony, oraz wyraźną konotację chrystologiczną obrazu $\mathrm{z}$ drugiej ${ }^{23}$. Bóg tragiczny nie wyłania się z przestrzeni wiary - ta bowiem legła już w gruzach - lecz ze zrodzonej w tragicznym doświadczeniu metafory, która nie może ocalić dzieci, mogłaby natomiast nadać sens ich śmierci. Mogłaby - tryb warunkowy, który się pojawia w tekście ewokującym ten obraz, jest wyrazem przepaści otwierającej się między poezją a wiarą. Cierpienie niewinnych dzieci, podniesione w poetyckich słowach do rangi mesjańskiej, a nawet przekraczające tę rangę w kierunku boskości („Każde z mych dzieci zgładzonych mogłoby stać się Bogiem!"), konstytuuje obraz skazany na pozostanie poza przestrzenią wiary, zrodził się bowiem z doświadczenia grzebiącego wiarę. Zastępują ją bunt i rozpacz, które okazują się jedyną drogą dla ocalenia nieskazitelnej świętości tego obrazu. To nie Bóg żydowskiej teologii ocala dzieci, lecz rozpaczający i oskarżający ojciec ustanawia w obrazie zamęczonych dzieci nową, tragiczną normę boskości.

Niezwykłe w swej gwałtowności oskarżenie „niebios” ma tę samą podstawę, co oskarżenia formułowane przez Hioba: niewinność ofiar. Rozpad świata na świat ustanawiający zło i świat doznający zła nie podlega tu jakiejkolwiek dialektyce. Pozostają one od siebie radykalnie odseparowane. Nie ma żadnej instancji transcendentalnej, która mogłaby oba te światy objąć. Bóg Przymierza, którego nie odnajduje poeta w świecie Zagłady, jawi się w obrazie „niebios” jako „Bóg zgrozy”, analogon adresata Hiobowej skargi: „Bóg mnie zaprzedał złoczyńcom, oddał mnie w ręce zbrodniarzy" (Hi 16,11).

Nie należy jednak tracić z oczu, iż kluczowe dla pieśni IX obrazy motywowane są rozwijającym się schematem tragiczności transcendentalnej, a więc poszukiwaniem takiego obrazu Boga, który utożsamiałby się z najstraszniejszymi doświadczeniami ofiar. I taki obraz poeta odnajduje! Choć nie odnajduje wiary, by połączyć w jednej figurze - być może ocalającej Boga wiary - dwa antytetyczne obrazy: obraz tragicznego losu żydowskich dzieci o znamionach boskości z obrazem Boga zerwanego Przymierza. Innymi słowy, połączyć obraz Boga tragicznego, tożsamego z doświadczeniem najsłabszych i najbardziej cierpiących z obrazem Boga tragedii, który w swej transcendentalnej sprawczości

23 Problem konotacji chrześcijańskich obrazu „narodu okrutnie ukrzyżowanego” w poemacie Kacenelsona wymagałby osobnej analizy, przeprowadzonej subtelnie i uwzględniającej wszystkie istotne konteksty poematu, a także wszystkie jego semantyczne i stylistyczne tropy, w które konotacje te są uwikłane. Biorąc pod uwagę, jak historycznie nabrzmiały i delikatny jest „problem” Jezusa w teologii żydowskiej, a zarazem jak szczególnie dziś ważne jest dla chrześcijanina wewnętrzne ujęcie tej kwestii przez teologię żydowską, ramy teologiczne dla takiej analizy przeprowadzonej „od strony chrześcijańskiej” stanowić mogłoby ujęcie R.B.L. Sherwina, A wy za kogo mnie uważacie? Żydowska odpowiedź na pytanie Jezusa, tłum. T. Dębski, „Znak” 2013, nr 10. 
ujawnia oblicze „zgrozy”. Obrazy „pustych niebios” i „wniebowstąpienia” zamęczonych dzieci dzieli przepaść analogiczna do przepaści między światem ustanawiającym i światem doznającym zła totalnej i radykalnie bezpodstawnej eksterminacji. Dla poety jest to przepaść możliwa do wypełnienia jedynie głosem rozpaczy, oskarżenia i klątwy. Wyłaniająca się z tego głosu figura tragiczności transcendentalnej, rozwijająca się niejako równolegle do linii rozpaczy, jest w swym dążeniu ocalającym równie stanowcza i przejmująca, jak obraz Boga cierpiącego, głoszony w getcie warszawskim przez rabbiego Shapirę.

Kryzys wiary w obliczu Holokaustu - biorąc pod uwagę tylko dwa analizowane przypadki - ujawnił się w tragicznej niewspółmierności odległego Boga wiary i przerażającej rzeczywistości pozbawionej nadziei na ocalenie. „Bóg cierpiący” z kazań rabbiego Shapiry i „okrutne ukrzyżowanie” z poematu Kacenelsona to dramatyczne próby ocalenia Boga wiary w piekle Endlösung.

\section{Bibliografia}

Abramson H., Torah from the Years of Wrath 1939-1943: The Historical Context of the "Aish Kodesh”, New York 2017.

Dialogue at the Edge of Auschwitz - Perspectives for a Theology After Auschwitz, Kraków, Oświęcim 2014.

Holokaust a teodycea, red. J. Diatłowicki, K. Rąb, I. Sobieraj, Kraków 2008.

Jonas H., Idea Boga po Auschwitz, tłum. G. Sowinski, Kraków 2003.

Kacenelson I., Pieśn o zamordowanym żydowskim narodzie, tłum., wstęp, przyp. J. Ficowski, Warszawa 1986.

Korczak J., Pamiętnik i inne pisma z getta, Warszawa 2012.

Murphy R.E., Ksiega Hioba, tłum. H. Bednarek [w:] Międzynarodowy komentarz do Pisma Świętego, red. W.R. Farmer, Warszawa 2001.

Pawelec A., Sitarz M., Ostatni Żyd w Europie, „Pieśn o zamordowanym żydowskim narodzie” Jicchoka Kacenelsona, „Zeszyty Naukowe Centrum Badań im. Edyty Stein" 2014, nr 12.

Pelletier A.-M., Księga Izajasza [w:] Międzynarodowy komentarz do Pisma Świętego, red. W.R. Farmer, Warszawa 2001.

Pismo Święte, według wyd. 4 Biblii Tysiąclecia, oprac. Zespół Papieskiego Wydziału Teologicznego w Poznaniu, Poznań 1998, http://biblia.deon.pl/, dostęp: 4.07.2018.

Polen N., The Holy Fire: The Teachings of Rabbi Kalonymus Kalman Shapira, the Rebbe of the Warsaw Ghetto, New Jersey 1994.

Ricoeur P., Symbolika zła, tłum. S. Cichowicz, M. Ochab, Warszawa 1986.

Rahner K., O możliwości wiary dzisiaj, tłum. A. Morawska, Kraków 1983.

Rahner K., Vorgrimler H., Maty stownik teologiczny, tłum. T. Mieszkowski, P. Pachciarek, Warszawa 1996. 
Rubenstein R., After Auschwitz. Radical Theology and Contemporary Judaism, New York 1966.

Shapira K., Sacred Fire: Torah from the Years of Fury, 1939-1942, transl. J.H. Worch, New Jersey, Jerusalem 2000.

Sherwin R.B.L., A wy za kogo mnie uważacie? Żydowska odpowiedź na pytanie Jezusa, tłum. T. Dębski, „Znak” 2013, nr 10.

[Szapira K.K. Rabbi], Sefer Aish Kodesh, Vaad Hasidey, Piaseczno, Jerusalem 1960.

Szapira K.K. Rabbi, Święty ogień. Tora z lat 1939-1942, lat szatu, wyb., wstęp W. Mędykowski, tłum. I. Kania, „Znak” 2006, nr 4.

Śpiewak P., Kaznodzieja getta warszawskiego, „Znak” 1996, nr 3.

Taniec opowieści, czyli chasydzi Piaseczna, www.studnia.org/piaseczno.ramka.htm, dostęp: 13.09.2018.

Teologia i filozofia żydowska wobec Holocaustu, wstęp, wyb., oprac. P. Śpiewak, Gdańsk 2013.

Tyszczyk A., „Do niebios” Icchaka Kacenelsona [w:] Literatura polsko-żydowska. Studia i szkice, red. E. Prokop-Janiec, S.J. Żurek, Kraków 2011.

Tyszczyk A., W kręgu tragiczności: Księga Hioba. Fragment większego fragmentu, „Roczniki Humanistyczne” 2009, z. 1.

Zuberbier A., Teologia katolicka po Holokauście, „Znak” 1996, nr 3. 